\title{
Effect of Iberian pig feeding system on tissue fatty-acid composition and backfat rheological properties*
}

\author{
A. Daza ${ }^{1}$, D. Menoyo ${ }^{1,3}$, A. Olivares ${ }^{2}$, G. Cordero ${ }^{2}$ \\ and C.J. López-Bote ${ }^{2}$ \\ ${ }^{1}$ Department of Animal Production, School of Agriculture, \\ Polytechnic University of Madrid \\ 28040 Madrid, Spain \\ ${ }^{2}$ Department of Animal Producion, Veterinary Faculty of Complutense University \\ 28040 Madrid, Spain
}

(Received 22 November 2006; revised version 6 June 2007; accepted 6 September 2007)

\begin{abstract}
The present study aims to determine the effect of feeding system for Iberian pigs during the fattening period on tissue fatty-acid composition and rheological properties. Twenty-four Iberian barrows of the same age with an average initial liveweight of $100.2 \mathrm{~kg}$ were randomly distributed into three groups of eight pigs each. One group was fed under free-range conditions for $117 \mathrm{~d}$. The other two groups were fed in confinement either with acorns from Quercus rotundifolia or a concentrate diet. Differences on subcutaneous backfat fatty-acid composition were found among feeding systems with the outer layer of backfat in concentrate-fed pigs containing more SFA and total n-6 and less MUFA, directly reflecting dietary fatty-acid composition. The longissimus dorsi intramuscular neutral lipids (NL) of free-range pigs contained higher C18:1 n-9, MUFA and lower SFA proportions than those fed with acorns or the concentrate diet. The liver NL in pigs fed acorns in confinement contained higher C18:1 n-9, MUFA and lower SFA proportions than those fed a concentrate diet or in free-range. Subcutaneous fat from pigs fed the concentrate diet was higher in hardness than those fed acorns in confinement or in free-range, while adhesiveness was higher in pigs fed acorns in confinement than in the remaining groups of pigs.
\end{abstract}

KEY WORDS: fat, free-range, confinement feeding, fatty acid profile, rheological properties, Iberian pig

\footnotetext{
* Supported by INIA RTA 2004-00053

${ }^{4}$ Corresponding author: e-mail: david.menoyo@upm.es
} 


\section{INTRODUCTION}

The Iberian pig is an autochthonous breed from the south-west Iberian peninsula traditionally fattened with acorns and grass in an outdoor free-range production system. Meat products from the Iberian pig are highly acceptable for consumers willing to pay a premium for the quality characteristics closely linked to the extensive feeding system (López-Bote, 1998). Moreover, there is increasing consumer concern about biodiversity, preservation of threatened environmental areas, as it is the case with the Mediterranean forest, etc. (López-Bote, 1998). Also, conventional intensive pork production is focusing attention on alternative rearing systems, including free-range conditions, because of animal welfare issues and the increasing demand for meat products not produced intensively (Bee et al., 2004). Although there may be some positive implications for pig welfare, the relation of a pig's physical activity to slaughter yield and meat quality characteristics is unclear (Millet et al., 2005). However, there is evidence of a higher nutritional value of the fat (lower deposition and more unsaturated). Moreover, technological properties (softer fat more prone to oxidative processes) may also be affected (Bee et al., 2004).

The Iberian pig carcass fatty-acid composition is characterized by the lower endogenous fatty acid synthesis observed in the exercised pigs, together with the high concentration of monounsaturated fatty acids (particularly oleic acid C18:1 n-9) provided by the acorn. This results in a carcass rich in C18:1 n-9 $(>50 \%)$ and with a very low concentration of palmitic $(\mathrm{C} 16: 0)$ and stearic (C18:0) acids (below 21 and 9.5\%, respectively) (De Pedro, 2001). Therefore, the meat from these pigs is more "healthy" from a nutritional point of view than that of conventional pigs, which provides further reasons for its consumption. The carcass value of the Iberian pig is set in the market according to the major fatty acid proportion in the subcutaneous fat, particularly regarding the $\mathrm{C} 18: 1$ n-9 contents.

Although it is a matter of interest in many other productive circumstances, there is, to our knowledge, limited information on the influence of feeding system during the finishing period on Iberian pig fat quality and subcutaneous fat rheological properties. Therefore, the main objective of this experiment was to asses the effects of feeding system during the Iberian pig fattening period on the fatty-acid composition of subcutaneous backfat (outer and inner layer) and longissimus dorsi muscle intramuscular and liver lipids (neutral and polar lipids) and subcutaneous backfat rheological properties. 


\section{MATERIAL AND METHODS}

\section{Animals, experimental design and diets}

Twenty-four Iberian barrows of the Torbiscal line of the same age with an average initial liveweight of $100.2 \mathrm{~kg}$ ( $\mathrm{SEM}=2.2 \mathrm{~kg}$ ) were randomly distributed into three groups of eight pigs each. One group was fed under outdoor free-range conditions with acorns from Quercus rotundifolia and grass for 117 days. The other two groups were located in individual cages and fed in confinement either only with acorns or a concentrate diet during the same period. The average daily amount (restrictive feeding) given of acorns and feed was 4.0 and $3.01 \mathrm{~kg}$, respectively.

\section{Measurements and analysis}

Composition analysis of the acorns, grass and concentrate diet given during the fattening period was carried out according to AOAC (1990). Fat of the concentrate diet, acorn and grass was analysed by the one-step procedure described by Sukhija and Palmquist (1988) in lyophilized samples. Methylated fatty acid samples were identified by gas chromatography as described elsewhere (Rey and López-Bote, 2001) using a 6890 Hewlett Packard gas chromatograph and a $30 \mathrm{~m} \times 0.32 \mathrm{~mm} \times 0.25 \mu \mathrm{m}$ cross-linked polyethylene glycol capillary column. Individual methyl esters were identified by comparison with standards and by reference to published data (Ruiz et al., 1998; Lopez-Bote et al., 2002).

Pigs were slaughtered at a local slaughterhouse at an average weight of 147.6 $\mathrm{kg}(\mathrm{SEM}=4.30 \mathrm{~kg})$. Carcass weight and backfat thickness over the last rib were recorded. A sample of backfat from over the last rib was then removed and separated into inner and outer layers that were independently analysed for fatty-acid composition. A sample of longissimus dorsi muscle from over the last rib, and a liver sample were also taken for fatty acid analysis. Lipids from subcutaneous fat were extracted by the method proposed by Bligh and Dyer (1959), while neutral (NL) and polar lipids (PL) from muscle and liver samples were obtained according to the procedure developed by Marmer and Maxwell (1981). Fat extracts were methylated and analysed by gas chromatography as described by Rey and López-Bote (2001).

The rheological properties of subcutaneous fat were determined by means of a TA.XT texture analyser (Stable Micro Systems, Surrey, UK) equipped with a cylindrical P25 probe. The following parameters were defined: hardness $(\mathrm{H})=$ maximum strength required to achieve compression; area of the first compression (A1) = total energy required for the first compression; area of the second compression (A2) = total energy required for the second compression; adhesiveness $=$ area under the abscissa after the first compression; cohesiveness $(\mathrm{C})=\mathrm{A} 2 / \mathrm{A} 1$; gumminess $(\mathrm{G})=\mathrm{H} \times \mathrm{C}$; chewiness $(\mathrm{Ch})=\mathrm{S} \times \mathrm{G}$. To this end backfat samples of $2.5 \mathrm{~cm}$ diameter and $0.8 \mathrm{~cm}$ thick were removed and measurements performed at $6 \pm 1^{\circ} \mathrm{C}$. Three different samples were obtained from each pig and analysed independently. The texture analysis of subcutaneous fat was limited to the inner layer. 


\section{Statistical analysis}

An individual pig was the experimental unit for all data analysis. Statistical analysis was performed by means of analysis of variance using the general linear models procedure contained in SAS (1999). Feeding system was the effect studied. The Student t-test was used to compare the fatty acid composition of outer and inner subcutaneous backfat layers. Data are presented as the mean and pooled standard error (SEM). A correlation procedure was also carried out to study the relations among backfat thickness, longissimus dorsi intramuscular fat percentage and hepatic fat percentage. Statistical significance was set at $\mathrm{P}<0.05$.

\section{RESULTS AND DISCUSSION}

Chemical composition of the experimental concentrate diet and acorn and grass is provided in Table 1.

Table 1. Chemical composition of experimental mixed diet, acorn and grass

\begin{tabular}{|c|c|c|c|c|}
\hline & \multirow{2}{*}{ Concentrate $^{1}$} & \multirow{2}{*}{ Grass } & \multicolumn{2}{|c|}{ Acorns } \\
\hline & & & confinement & free-range \\
\hline \multicolumn{5}{|l|}{ Nutrients } \\
\hline dry matter (DM), g/kg & 891.1 & 222.4 & 686.6 & 677.2 \\
\hline \multicolumn{5}{|l|}{$\mathrm{g} / \mathrm{kg} \mathrm{DM}$} \\
\hline crude protein & 141.3 & 143.9 & 46.3 & 49.2 \\
\hline crude fat & 31.0 & 63.9 & 69.6 & 65.4 \\
\hline crude fibre & 45.2 & 234.1 & 59.1 & 56.2 \\
\hline $\mathrm{N}$-free extractives & 770.2 & 488.2 & 809.9 & 813.4 \\
\hline ash & 12.3 & 69.9 & 15.1 & 15.8 \\
\hline$\alpha$-tocopherol & 95.9 & 245.6 & 34.5 & 33.4 \\
\hline \multicolumn{5}{|c|}{ Fatty acids, $g / 100 \mathrm{~g}$ total fatty acids ${ }^{2}$} \\
\hline $\mathrm{C} 12: 0$ & 0.05 & 0.23 & 0.02 & 0.02 \\
\hline C14:0 & 0.80 & 0.43 & 0.07 & 0.08 \\
\hline C15:0 & - & 0.21 & 0.06 & 0.05 \\
\hline $\mathrm{C} 16: 0$ & 23.70 & 15.48 & 12.63 & 12.21 \\
\hline $\mathrm{C} 17: 0$ & 0.20 & 0.25 & 0.12 & 0.11 \\
\hline C18:0 & 9.37 & 2.12 & 3.56 & 3.31 \\
\hline C16:1 n-7 & 1.33 & 0.34 & 0.09 & 0.09 \\
\hline C16:1 n-9 & 0.06 & 2.57 & 0.05 & 0.05 \\
\hline C18:1n-7 & 0.6 & 1.11 & 0.34 & 0.30 \\
\hline C18:1 n-9 & 30.29 & 9.25 & 62.9 & 65.3 \\
\hline C18:2 n-6 & 28.72 & 11.4 & 13.8 & 14.2 \\
\hline C18:3 n-3 & 3.15 & 46.94 & 1.07 & 1.06 \\
\hline $\mathrm{C} 20: 0$ & 0.15 & 0.07 & 0.29 & 0.31 \\
\hline
\end{tabular}

${ }^{1}$ concentrate contained, $\mathrm{g} / \mathrm{kg}$ : barley 532.8 , wheat 310.5 , sunflower seed 50.1 , soyabean meal (44\%) 81.0, calcium carbonate 8.2 , dicalcium phosphate 9.1 , sodium chloride 4 , mineral-vitamin premix 4 ${ }^{2}$ other fatty acids: C10:0, C15:1, C17:1, C20:1, C18:4n-3, C20:3n-9 
No significant differences in average daily gain during the fattening period were observed among pigs fed the concentrate diet in confinement, free-range pigs and pigs fed in confinement only with acorns for 117 days $(426.5,395.0$ and $394.0 \mathrm{~g}(\mathrm{SEM}=16.4)$, respectively. Also slaughter and carcass weights were similar regardless of feeding system 149.2, 147,4 and $146.2 \mathrm{~kg}(\mathrm{SEM}=4.30)$ and $119.4,116.5$ and $116.7 \mathrm{~kg}(\mathrm{SEM}=3.82)$, respectively.

Pigs were subjected to the same feeding programme and received a commercial diet from $40 \mathrm{~kg}$ to the beginning of the experimental period. Therefore, the same fatty-acid composition was observed at the beginning of the trial (data not shown). Fatty-acid composition and melting point of the outer and

Table 2 . Fatty acid composition ( $\mathrm{g} / 100 \mathrm{~g}$ total fatty acids) and melting point (MP in ${ }^{\circ} \mathrm{C}$ ) of the outer (a) and inner (b) subcutaneous backfat layers according to the feeding system

\begin{tabular}{|c|c|c|c|c|c|}
\hline \multicolumn{6}{|c|}{ Feeding system } \\
\hline Item & $\begin{array}{c}\text { acorns in } \\
\text { confinement }\end{array}$ & free-range & $\begin{array}{l}\text { concentrate diet in } \\
\text { confinement }\end{array}$ & SEM $^{1}$ & $P$ value \\
\hline \multicolumn{6}{|l|}{ Fatty acid (a) } \\
\hline C16:0 & $19.39^{\mathrm{a}}$ & $18.92^{\mathrm{a}}$ & $19.99^{\mathrm{b}}$ & 0.17 & 0.0009 \\
\hline C18:0 & 8.54 & 8.14 & 9.20 & 0.29 & 0.057 \\
\hline C18:1 n-9 & $49.49^{\mathrm{a}}$ & $51.53^{\mathrm{b}}$ & $46.31^{\mathrm{c}}$ & 0.42 & 0.0001 \\
\hline C18:2 n-6 & $11.93^{\mathrm{a}}$ & $11.04^{\mathrm{b}}$ & $12.96^{\mathrm{c}}$ & 0.19 & 0.0001 \\
\hline C18:3 n-3 & $0.67^{\mathrm{a}}$ & $0.62^{\mathrm{a}}$ & $0.77^{\mathrm{b}}$ & 0.023 & 0.0011 \\
\hline $\mathrm{SFA}^{2}$ & $29.65^{\mathrm{a}}$ & $28.66^{\mathrm{a}}$ & $30.92^{\mathrm{b}}$ & 0.41 & 0.004 \\
\hline MUFA $^{3}$ & $56.19^{\mathrm{a}}$ & $58.30^{\mathrm{b}}$ & $53.76^{\mathrm{c}}$ & 0.43 & 0.00001 \\
\hline PUFA $^{4}$ & $14.15^{\mathrm{a}}$ & $13.04^{\mathrm{b}}$ & $15.32^{\mathrm{c}}$ & 0.23 & 0.00001 \\
\hline$n-6^{5}$ & $12.11^{\mathrm{a}}$ & $11.20^{\mathrm{b}}$ & $13.14^{\mathrm{c}}$ & 0.20 & 0.00001 \\
\hline$n-3^{6}$ & 1.14 & 1.01 & 1.18 & 0.053 & 0.09 \\
\hline$n-6 / n-3$ & 10.90 & 11.10 & 11.21 & 0.45 & 0.89 \\
\hline MP & 26.39 & 26.08 & 28.33 & 0.86 & 0.30 \\
\hline \multicolumn{6}{|l|}{ (b) } \\
\hline C16:0 & $20.75^{\mathrm{a}}$ & $19.12^{\mathrm{b}}$ & $21.76^{\mathrm{c}}$ & 0.21 & 0.00001 \\
\hline C18:0 & $11.13^{\mathrm{a}}$ & $9.67^{b}$ & $13.05^{\mathrm{c}}$ & 0.48 & 0.0003 \\
\hline C18:1 n-9 & $48.46^{\mathrm{a}}$ & $52.67^{\mathrm{b}}$ & $44.99^{c}$ & 0.89 & 0.00001 \\
\hline C18:2 n-6 & 9.81 & 10.28 & 10.15 & 0.28 & 0.48 \\
\hline C18:3 n-3 & 0.54 & 0.58 & 0.61 & 0.028 & 0.29 \\
\hline $\mathrm{SFA}^{2}$ & $33.58^{\mathrm{a}}$ & $30.31^{\mathrm{b}}$ & $36.59^{c}$ & 0.62 & 0.00001 \\
\hline MUFA $^{3}$ & $54.93^{\mathrm{a}}$ & $57.72^{b}$ & $51.29^{\mathrm{c}}$ & 0.58 & 0.00001 \\
\hline PUFA $^{4}$ & 11.49 & 11.97 & 12.12 & 0.34 & 0.42 \\
\hline$n-6^{5}$ & 9.97 & 10.44 & 10.31 & 0.29 & 0.49 \\
\hline$n-3^{6}$ & 0.85 & 0.86 & 0.99 & 0.063 & 0.24 \\
\hline$n-6 / n-3$ & 11.97 & 12.27 & 10.80 & 0.59 & 0.21 \\
\hline MP & 31.44 & 29.55 & 32.08 & 0.99 & 0.23 \\
\hline
\end{tabular}

${ }^{1}$ SEM - pooled standard error. Within row means with different superscripts are significantly different $(\mathrm{P}<0.05) ;{ }^{2} \mathrm{SFA}$ - total saturated fatty acids includes: C10:0, C12:0, C14:0, C15:0, C16:0, C18:0, C20:0; ${ }^{3}$ MUFA - total monounsaturated fatty acids includes: C15:1, C16:1n-9, C16:1n-7, C17:1, C18:1n-9, C20:1; ${ }^{4}$ PUFA - total polyunsaturated fatty acids includes: C18:2 n-6, C18:3 n-3, C18:4n-3, C20:4n-6, C20:3n-9, C20:5n-3, C22:5n-3, C22:6n-3; ${ }^{5}$ n-6 includes: C18:2 n-6, C20:4n$6 ;{ }^{6}$ n-3 includes: C18:3 n-3, C18:4n-3, C20:5n-3, C22:5n-3, C22:6n-3 
inner subcutaneous backfat layers are shown in Table 2. As expected the outer and inner subcutaneous backfat layers from pigs fed the concentrate diet in confinement had higher C16:0 and total saturated fatty acids (SFA) and lower C18:1 n-9 and monounsaturated fatty acids (MUFA) than pigs fed with acorns during the fattening period. However, González et al. (2005) found no differences in subcutaneous backfat C18:1 n-9 and MUFA proportions when comparing Iberian pigs fed free-range or fed in confinement with a concentrate diet rich in C18:1 n-9. The outer subcutaneous backfat layer in pigs fattened under free-range conditions showed higher C18:1 n-9, MUFA and lower C18:2 n-6 polyunsaturated fatty acids (PUFA) and n-6 concentrations than pigs fed with acorn in confinement. Nevertheless, no differences on such fatty acid proportions were observed by López Carrasco et al. (2003) and Rey et al. (2006) when comparing pigs fed in free-range and only with acorns in confinement. Pigs fed under free-range conditions contained higher C18:1 n-9, MUFA and lower C16:0, C18:0 and SFA concentrations in the inner subcutaneous backfat layer than those fed only with acorns in confinement. López Carrasco et al. (2003) and Rey et al. (2006) also observed a higher percentage of C18:1 n-9 in the inner subcutaneous backfat layer of free-range pigs when compared with pigs fed acorns in confinement. Higher C18:1 n-9 concentration was observed in the outer and inner subcutaneous backfat layers in the free-range pigs (fed acorns and grass) with respect to those fed only with acorns in confinement. This may be explained by the high $\alpha$-tocopherol contents in the grass (Daza et al., 2005a), since $\alpha$-tocopherol seems to have a positive effect on delta-9 desaturase activity (Okayasu et al., 1977).The inner layer had higher SFA and lower PUFA than the outer layer, which is in agreement with the results obtained by Migdal et al. (2001) and López-Bote et al. (2002). However, it is interesting to note that in the present study C18:1 n-9 and MUFA proportions were higher in the inner than in the outer layer in free-range pigs. Backfat $\mathrm{C} 18: 3 n-3$ and total n-3 concentrations were unaffected in the free-range pigs despite the relatively high concentration of this fatty acid observed in the grass. Under free range conditions a significant amount of grass is available only at the end of the fattening period. Taking into account that dietary fatty-acid composition reflects backfat fatty acid profile in the long term, and not in the short term, as in the more active tissues like the liver, it seems plausible to relate the lack of effect of grass 18:3 n-3 concentration on backfat to the short period of grass intake.

The feeding system did not affect outer and inner subcutaneous backfat melting points. López-Bote et al. (2002) were unable to detect differences in fat melting points in the outer and inner backfat layers in regard to dietary fatty-acid composition. However, as in our study, they detected a higher melting point value in the inner than in the outer layer, which can be explained by the higher SFA content in the former. 
The intramuscular fat percentage is closely related to meat tenderness and flavour (López-Bote, 1998). The longissimus dorsi intramuscular fat percentages (LDIF) in pigs fed only with acorns in confinement, free-range pigs and pigs fed the concentrate diet in confinement were 8.54, 7.94 and 7.24\% (SEM=0.51), respectively. These LDIF percentages were higher than those observed by Muriel et al. (2004) and Daza et al. (2005b) in Iberian pigs of the Torbiscal line at similar slaughter weights. Backfat thickness were 48.83, 47.37 and $46.62 \mathrm{~mm}$ $(\mathrm{SEM}=0.20 ; \mathrm{P}>0.05)$ in free-range, acorn in confinement and concentrate fed pigs, respectively. According to our results, pigs fed with acorns in confinement tended $(\mathrm{P}<0.1)$ to have a higher LDIF percentage than those fed the concentrate diet in confinement. This may be a result of the higher fat content supplied by the acorns. Also, Tejeda et al. (2002) found a higher total intramuscular lipid content in free-range pigs (fed acorn and grass) than in pigs fed a mixed diet. No significant correlations between carcass weight and LDIF percentage and between backfat thickness and LDIF percentage were observed $(\mathrm{r}=0.18$ and $\mathrm{r}=0.09$, respectively).

The fatty-acid composition of intramuscular NL and PL in longissimus dorsi muscle is shown in Table 3. The intramuscular NL contained higher C18:1 n-9, MUFA, lower C16:0, C18:0, SFA and similar C18:2 n-6, C18:3 n-3, PUFA, n- 6 and n-3 concentrations in the free-range pigs than in those fed the acorns or the concentrate diet in confinement. These results are in accordance with those obtained by Daza et al. (2005a) in longissimus dorsi muscle and Petrón et al. (2005) in biceps femoris muscle from Iberian pigs when comparing free-range pigs and pigs fed a concentrate diet. Also, Rey et al. (2006) observed similar results as those obtained in this experiment. However, they detected higher C18:2 n-6 and n-6 concentrations in longissimus dorsi intramuscular NL in pigs fed a concentrate diet rich in C18:2 n-6, than in those under free-range conditions or those fed the acorn in confinement.

Pigs raised under free-range conditions showed lower C16:0 and SFA in the intramuscular PL fraction than those fed the acorns or a mixed diet in confinement. The C18:1 n-9 and MUFA proportions in the intramuscular PL fraction were lower in the free-range pigs than in pigs fed the acorn in confinement and similar in free-range pigs and pigs fed the concentrate diet, while C18:2 n-6, PUFA, n-6, C18:3n-3 and n-3 concentrations were higher in free-range pigs than in those fed acorns in confinement, and similar in free-range pigs and in pigs fed the concentrate diet. These results are in accordance with Rey et al. (2006), but Cava et al. (1997) and Daza et al. (2005a) observed a higher C18:1 n-9 proportion in longissimus dorsi intramuscular PL in Iberian pigs raised under free-range conditions than in those fed a formulated diet in confinement. However, Rey et al. (1997) were unable to detect differences in C18:1 $\mathrm{n}-9, \mathrm{C} 18: 2 \mathrm{n}-6, \mathrm{n}-6$ and n-3 proportions in microsome extracts from longissimus dorsi muscle when free-range and mixed diet fed pigs were compared. 
Table 3. Fatty acid composition (g/100g total fatty acids) of intramuscular neutral (a) and polar (b) lipids in Longissimus dorsi muscle according to the feeding system

\begin{tabular}{|c|c|c|c|c|c|}
\hline & \multicolumn{3}{|c|}{ Feeding system } & \multirow[b]{2}{*}{ SEM $^{1}$} & \multirow[b]{2}{*}{$P$ value } \\
\hline Total fat, $\mathrm{g} / 100 \mathrm{~g}$ & $\begin{array}{c}\text { acorn in } \\
\text { confinement }\end{array}$ & free-range & $\begin{array}{l}\text { concentrate diet in } \\
\text { confinement }\end{array}$ & & \\
\hline \multicolumn{6}{|l|}{ Fatty acid (a) } \\
\hline C16:0 & $24.68^{\mathrm{a}}$ & $23.09^{b}$ & $24.27^{\mathrm{a}}$ & 0.35 & 0.011 \\
\hline C18:0 & $11.22^{\mathrm{a}}$ & $10.05^{\mathrm{b}}$ & $11.64^{\mathrm{a}}$ & 0.24 & 0.0003 \\
\hline C18:1 n-9 & $47.81^{\mathrm{a}}$ & $50.14^{b}$ & $47.19^{\mathrm{a}}$ & 0.38 & 0.0001 \\
\hline C18:2 n-6 & 4.02 & 4.55 & 4.17 & 0.25 & 0.33 \\
\hline C18:3 n-3 & 0.21 & 0.26 & 0.25 & 0.015 & 0.08 \\
\hline $\mathrm{SFA}^{2}$ & $37.69^{a}$ & $34.79^{\mathrm{b}}$ & $37.70^{\mathrm{a}}$ & 0.56 & 0.0016 \\
\hline MUFA $^{3}$ & $56.68^{\mathrm{a}}$ & $59.18^{\mathrm{b}}$ & $56.28^{\mathrm{a}}$ & 0.42 & 0.0001 \\
\hline PUFA $^{4}$ & 5.63 & 6.03 & 6.01 & 0.61 & 0.87 \\
\hline$n-6^{5}$ & 4.22 & 4.77 & 4.40 & 0.26 & 0.35 \\
\hline$n-3^{6}$ & 1.18 & 1.03 & 1.09 & 0.47 & 0.97 \\
\hline$n-6 / n-3$ & 7.06 & 6.62 & 6.77 & 1.04 & 0.95 \\
\hline \multicolumn{6}{|l|}{ (b) } \\
\hline C16:0 & $23.46^{\mathrm{a}}$ & $21.86^{\mathrm{b}}$ & $22.79^{\mathrm{a}}$ & 0.30 & 0.0048 \\
\hline C18:0 & 9.90 & 9.62 & 10.25 & 0.29 & 0.32 \\
\hline C18:1 n-9 & $39.53^{\mathrm{a}}$ & $33.84^{b}$ & $35.43^{\mathrm{ab}}$ & 1.40 & 0.026 \\
\hline C18:2 n-6 & $11.55^{\mathrm{a}}$ & $16.14^{b}$ & $13.30^{\mathrm{ab}}$ & 1.22 & 0.045 \\
\hline C18:3 n-3 & $0.26^{\mathrm{a}}$ & $0.31^{\mathrm{b}}$ & $0.32^{\mathrm{b}}$ & 0.016 & 0.04 \\
\hline SFA $^{2}$ & $34.78^{\mathrm{a}}$ & $32.65^{b}$ & $34.39^{\mathrm{a}}$ & 0.59 & 0.041 \\
\hline MUFA $^{3}$ & $47.99^{\mathrm{a}}$ & $41.64^{\mathrm{b}}$ & $44.36^{\mathrm{ab}}$ & 1.54 & 0.028 \\
\hline PUFA $^{4}$ & $17.22^{\mathrm{a}}$ & $25.71^{\mathrm{b}}$ & $21.25^{\mathrm{ab}}$ & 1.96 & 0.021 \\
\hline$n-6^{5}$ & $15.61^{\mathrm{a}}$ & $22.93^{b}$ & $18.45^{\mathrm{ab}}$ & 1.75 & 0.025 \\
\hline$n-3^{6}$ & $1.33^{\mathrm{a}}$ & $2.41^{\mathrm{b}}$ & $2.15^{\mathrm{b}}$ & 0.21 & 0.054 \\
\hline$n-6 / n-3$ & $11.74^{\mathrm{a}}$ & $9.63^{\mathrm{b}}$ & $8.74^{\mathrm{b}}$ & 0.56 & 0.0037 \\
\hline
\end{tabular}

The liver fat (LF) percentages were 6.18, 6.04 and 5.25 (SEM=0.41) in pigs fed acorns in confinement, free-range pigs and pigs fed a concentrate diet, respectively. The pigs fed with acorns in confinement tended $(\mathrm{P}<0.08)$ to have a higher LF percentage than those fed a mixed diet, which agrees with López et al. (1990). No significant correlation coefficients between carcass weight and LF percentage, backfat thickness and LF percentage and LDIF and LF percentage were observed $(\mathrm{r}=-0.11, \mathrm{r}=0.05$ and $\mathrm{r}=0.05$, respectively).

The fatty-acid composition of liver NL and PL is presented in Table 4. Pigs fed a concentrate diet showed lower C18:1 n-9 and MUFA proportions in both liver lipid fractions than free-range animals and pigs fed acorns in confinement.

The C18:1 n-9, MUFA, C18:2 n-6 and C18:3 n-3 proportions in the liver NL and $\mathrm{PL}$ fractions of pigs fed acorns were higher than those from the pigs fed in free-range, whereas C18:0, SFA, PUFA and n-3 concentrations in liver PL were lower in pigs fed acorns than in the free-range group.

In accordance with Ruiz et al. (1998), the fatty-acid composition of intramuscular PL and liver NL and PL seems to reflect the feeding regime during the last phase of 
Table 4. Fatty acid composition ( $\mathrm{g} / 100 \mathrm{~g}$ total fatty acids) of neutral (a) and polar (b) lipids from liver fat according to feeding system

\begin{tabular}{|c|c|c|c|c|c|}
\hline \multicolumn{6}{|c|}{ Feeding system } \\
\hline Total fat, $\mathrm{g} / 100 \mathrm{~g}$ & $\begin{array}{c}\text { acorn in } \\
\text { confinemen } \\
6.18\end{array}$ & $\begin{array}{c}\text { free-range } \\
6.04\end{array}$ & $\begin{array}{c}\text { concentrate diet in } \\
\text { confinement } \\
5.25 \\
\end{array}$ & $\begin{array}{l}\text { SEM }^{1} \\
0.41\end{array}$ & $\begin{array}{c}P \text { value } \\
0.32\end{array}$ \\
\hline \multicolumn{6}{|l|}{ Fatty acid (a) } \\
\hline C16:0 & $15.05^{\mathrm{a}}$ & $11.20^{\mathrm{b}}$ & $14.52^{\mathrm{a}}$ & 0.58 & 0.0002 \\
\hline C18:0 & $17.13^{\mathrm{a}}$ & $23.48^{\mathrm{b}}$ & $22.37^{\mathrm{b}}$ & 0.96 & 0.0003 \\
\hline C18:1 n-9 & $35.71^{\mathrm{a}}$ & $26.38^{\mathrm{b}}$ & $20.71^{\mathrm{c}}$ & 1.11 & 0.00001 \\
\hline C18:2n-6 & $12.73^{\mathrm{a}}$ & $12.05^{\mathrm{b}}$ & $14.22^{c}$ & 0.21 & 0.00001 \\
\hline C18:3 n-3 & $0.51^{\mathrm{a}}$ & $0.30^{\mathrm{b}}$ & $0.55^{\mathrm{a}}$ & 0.031 & 0.00001 \\
\hline $\mathrm{SFA}^{2}$ & $33.73^{\mathrm{a}}$ & $35.56^{\mathrm{b}}$ & $38.18^{\mathrm{c}}$ & 0.57 & 0.0001 \\
\hline MUFA $^{3}$ & $41.61^{\mathrm{a}}$ & $30.54^{b}$ & $25.24^{\mathrm{c}}$ & 1.24 & 0.00001 \\
\hline PUFA $^{4}$ & $24.66^{\mathrm{a}}$ & $33.89^{\mathrm{b}}$ & $36.57^{\mathrm{b}}$ & 0.92 & 0.00001 \\
\hline$n-6^{5}$ & $13.25^{\mathrm{a}}$ & $12.35^{\mathrm{b}}$ & $14.76^{\mathrm{c}}$ & 0.23 & 0.00001 \\
\hline$n-3^{6}$ & $3.11^{\mathrm{a}}$ & $6.63^{\mathrm{b}}$ & $6.44^{\mathrm{b}}$ & 0.16 & 0.00001 \\
\hline$n-6 / n-3$ & $4.33^{\mathrm{a}}$ & $1.87^{\mathrm{b}}$ & $2.29^{\mathrm{c}}$ & 0.12 & 0.00001 \\
\hline \multicolumn{6}{|l|}{ (b) } \\
\hline $\mathrm{C} 16: 0$ & $13.36^{\mathrm{a}}$ & $13.01^{\mathrm{a}}$ & $15.72^{b}$ & 0.38 & 0.0001 \\
\hline C18:0 & $28.36^{\mathrm{a}}$ & $30.24^{\mathrm{b}}$ & $27.37^{\mathrm{a}}$ & 0.63 & 0.011 \\
\hline C18:1 n-9 & $21.39^{\mathrm{a}}$ & $18.88^{b}$ & $15.65^{\mathrm{c}}$ & 0.81 & 0.0003 \\
\hline C18:2 n-6 & $15.39^{\mathrm{a}}$ & $12.71^{\mathrm{b}}$ & $14.72^{\mathrm{a}}$ & 0.34 & 0.0001 \\
\hline C18:3 n-3 & $0.40^{\mathrm{a}}$ & $0.26^{\mathrm{b}}$ & $0.34^{\mathrm{c}}$ & 0.018 & 0.0002 \\
\hline SFA $^{2}$ & $42.61^{\mathrm{a}}$ & $43.96^{\mathrm{ab}}$ & $44.26^{\mathrm{b}}$ & 0.56 & 0.006 \\
\hline MUFA $^{3}$ & $24.75^{\mathrm{a}}$ & $21.82^{\mathrm{b}}$ & $18.73^{\mathrm{c}}$ & 0.88 & 0.0004 \\
\hline PUFA $^{4}$ & $32.63^{\mathrm{a}}$ & $34.22^{\mathrm{a}}$ & $37.03^{\mathrm{b}}$ & 0.90 & 0.0081 \\
\hline$n-6^{5}$ & $28.84^{\mathrm{a}}$ & $28.38^{\mathrm{a}}$ & $31.57^{\mathrm{b}}$ & 0.70 & 0.0084 \\
\hline$n-3^{6}$ & $3.51^{\mathrm{a}}$ & $5.54^{\mathrm{b}}$ & $5.20^{\mathrm{b}}$ & 0.29 & 0.0001 \\
\hline$n-6 / n-3$ & $8.44^{\mathrm{a}}$ & $5.14^{\mathrm{b}}$ & $6.36^{\mathrm{b}}$ & 0.44 & 0.0001 \\
\hline
\end{tabular}

$1,2,3,4,5,6$ - explanation see Table 2

the fattening period. The reduction of available acorns at the end of the fattening period under the free-range conditions would explain the reduction of C18:1 n-9 and MUFA proportions in intramuscular PL and the NL and PL liver lipids in the free-range group compared with acorns fed in confinement.

The influence of feeding system on texture analysis of the inner subcutaneous backfat layer is shown in Table 5. No effect of feeding system was observed on rheological properties except for hardness and adhesiveness. Pigs fed the concentrate diet showed higher values of fat hardness than those fed with acorns or in free-range, while the adhesiveness was higher in pigs fed with acorns in confinement than in the free-range group. There is little information on the influence of the feeding system on rheological properties of fat in Iberian pigs. Miller et al. (1990) reported a lower fat firmness in pigs receiving diets with a high PUFA content, but D'Arrigó et al. (2002) did not find effects of dietary fat on lard rheological parameters (hardness, adhesiveness, gumminess and chewiness). López-Bote et al. (2002) working with Large White $\times$ Great York pigs, showed 
Table 5. Texture analysis of inner subcutaneous backfat layer according to feeding system

\begin{tabular}{lcccl}
\hline \multirow{2}{*}{ Properties } & \multicolumn{4}{c}{ Feeding system } \\
\cline { 2 - 5 } & $\begin{array}{c}\text { acorn in } \\
\text { confinement }\end{array}$ & free-range & $\begin{array}{c}\text { concentrate diet in } \\
\text { confinement }\end{array}$ & SEM \\
\hline Hardness, N/cm ${ }^{2}$ & $138.2^{\mathrm{a}}$ & $146.1^{\mathrm{a}}$ & $208.1^{\mathrm{b}}$ & 6.2 \\
Adhesiveness, N*second & $-3.54^{\mathrm{a}}$ & $-1.39^{\mathrm{b}}$ & $-1.96^{\mathrm{ab}}$ & 0.53 \\
Cohesiveness & 0.31 & 0.25 & 0.22 & 0.03 \\
Gumminess, N/cm & 42.9 & 49.4 & 39.1 & 5.4 \\
Chewiness, N/cm & 0.35 & 0.35 & 0.28 & 0.06 \\
\hline
\end{tabular}

within row, means with different superscripts differed $\mathrm{P}<0.05$

SEM - pooled standard error

positive and negative relationships of subcutaneous fat hardness with the melting point and the unsaturation level, respectively, and Daza et al. (2005c) observed increased adhesiveness in the subcutaneous backfat in Iberian x Duroc pigs fed diets rich in PUFA or vitamin E.

\section{CONCLUSONS}

Iberian pigs raised under free-range conditions contain a healthier fatty acid profile in the subcutaneous backfat and the intramuscular longissimus dorsi NL fraction than those fed acorns or a concentrate diet in confinement. The subcutaneous backfat in pigs raised in confinement and fed with acorns contains a fatty-acid profile with higher commercial value than in pigs fed a concentrate diet. The fatty-acid composition of the inner subcutaneous backfat layer is a good indicator of the feeding background, whereas the intramuscular fatty acid profile in longissimus dorsi muscle and the liver lipids are poor indicators.

\section{ACKNOWLEDGEMENTS}

The authors are grateful to Remedios Prieto and Pilar Ciria for technical assistance.

\section{REFERENCES}

AOAC, 1990. Association of Official Analytical Chemists, Official Methods of Analysis. $17^{\text {th }}$ Edition. Arlington, VA

Bee G., Guex G., Herzog W., 2004. Free-range rearing of pigs during the winter: Adaptations in muscle fiber characteristics and effects on adipose tissue composition and meat quality traits. J. Anim. Sci. 82, 1206-1218

Bligh E.G., Dyer W.J., 1959. A rapid method of total lipid extraction and purification. Can. J. Biochem. Physiol. 37, 911-917 


\section{TISSUE FATTY ACID COMPOSITION AND BACKFAT PROPERTIES OF PIG}

Cava R., Ruiz J., López-Bote C.J., Martín L., García C., Ventanas J., Antequera T., 1997. Influence of finishing diet on fatty acid profile of intramuscular lipids, triglycerides and phospholipids in muscles of the Iberian pigs. Meat Sci. 45, 263-270

D’Arrigo M., Hoz L., López-Bote C.J., Cambero I., Pin C., Rey A.I., Ordóñez J.A., 2002. Effect of dietary linseed oil and $\alpha$-tocopherol on selected properties of pig fat. Can. J. Anim. Sci. 82, 339-346

Daza A., Mateos A., Rey A., López Bote C.J., 2005b. Effect of feeding level during the period previous to free-range fattening on growth and carcass characteristics in Iberian pigs. Span. J. Agr. Res. 3, 387-395

Daza A., Rey A.I., Isabel B., López-Bote C.J., 2005c. Effect of dietary vitamin E and partial replacement of poly-with monounsaturated fat on fatty acid patterns of backfat and intramuscular fat in heavy pigs (Iberian x Duroc). J. Anim. Physiol. Anim. Nutr. 89, 20-28

Daza A., Rey A.I., Ruiz J., López-Bote C.J., 2005a .Effects of feeding in free-range conditions or in confinement with different dietary MUFA/PUFA ratios and $\alpha$-tocopheryl acetate, on antioxidants accumulation and oxidative stability in Iberian pigs. Meat Sci. 69, 151-163

De Pedro E., 2001. Iberian pig carcasses and product quality (in Spanish). In: C. Buxadé, A. Daza (Editors). Porcino Ibérico: Aspectos Claves. Mundi Prensa, Madrid (Spain), pp. 589-621

González E., Olivares A., Tejeda J.F., 2005. Use of high oleic diets in Iberian pig feeding (in Spanish). Proceedings of III Dry Cured Ham World Congress on Science, Technology and Marketing. Teruel (Spain), pp. 375-377

López M. O., de la Hoz L., Cambero M. I., Gallardo E., Martín-Álvarez P. J., Ordóñez, J.A., 1990. Fatty acid composition of the lard, muscle and liver fat from pigs. $36^{\text {th }}$ International Congress of Meat Science and Technology, 1, 269-275

López-Bote C.J., 1998. Sustained utilization of the Iberian pig breed. Meat Sci. 49, 17-27

López-Bote C.J., Isabel B., Daza A., 2002. Partial replacement of poly-with monounsaturated fatty acids and vitamin E supplementation in pigs diets: effect on fatty acid composition of subcutaneous and intramuscular fat and on fat and lean firmness. Anim. Sci. 75, 349-358

López Carrasco C., Contreras J. M., Daza A., Rey A. I., López-Bote C.J., 2003. Fatty acid composition and carcass characteristics of Iberian pigs fed in either free-range or in confinement with acorns and grass or a formulated diet. Proceedings of $54^{\text {th }}$ EAAP Congress, Rome, p. 2

Marmer W.N., Maxwell R.J., 1981. Dry column method for the quantitative extraction and simultaneous class separation of lipids from muscle tissue. Lipids 16, 365-371

Migdal W., Borowiec F., Migdal M., Zivkovic B., Fabjan M., Gardzinska A., Nowicki J., Pasciak P., 2001. The composition of fatty acids of inner and outer crossbred fattenners' backfat. VI International Symposium "Systems of Animal Breeding and Economics of Animal Production at the Beginning of the New Millennium". Belgrade (Yugoslavia). Biotechnol. Anim. Husbandry 17 (5/6), 235-240

Miller M.F., Shackelford S.D., Hayden K.D., Reagan J.O., 1990. Determination of the alteration in fatty acid profiles, sensory characteristics and carcass traits of swine fed elevated levels of monounsaturated fats in the diets. J. Anim. Sci. 68, 1624-1631

Millet S., Raes K., Van den Broeck W., De Smet S., Janssens G.G.P.J., 2005. Performance and meat quality of organically versus conventionally fed and housed pigs from weaning till slaughtering. Meat Sci. 69, 335-341

Muriel E., Ruiz J., Ventanas J., Petrón M. J., Antequera T., 2004. Meat quality characteristics in differents lines of Iberian pigs. Meat Sci. 67, 299-307

Okayasu T., Kameda K., Ono T., Imai Y., 1977. Effect of dietary vitamin B2 and vitamin E on the delta-9 desaturase and catalase activities in rat liver microsomes. Biochim. Biophys. Acta 489, 389-402

Petrón M.J., Muriel E., Pérez T., Antequera T., 2005. Effects of feeding system on Iberian ham lipid quality (in Spanish). Proceedings of III Dry Cured Ham World Congress on Science, Technology and Marketing. Teruel (Spain), pp. 371-373 
Rey A.I., Daza A., López Carrasco C., López-Bote C.J., 2006. Feeding Iberian pigs with acorns and grass in either free-range or confinement affects the carcass characteristics and fatty acids and tocopherols accumulation in longissimus dorsi muscle and backfat. Meat Sci. 73, 66-74

Rey A., López Bote C.J., 2001. Effect of dietary copper and vitamin E supplementation, and extensive feeding with acorns and grass on Longissimus dorsi muscle composition and susceptibility to oxidation in Iberian pigs. J. Anim. Physiol. Anim. Nutr. 85, 281-292

Rey A.I., López-Bote C.J., Sanz Arias R., 1997. Effect of extensive feeding on $\alpha$-tocopherol concentration and oxidative stability of muscle microsomes from Iberian pigs. Anim. Sci. 65, $515-520$

Ruiz J., Cava R., Antequera T., Martín L., Ventanas J., López-Bote C.J., 1998. Prediction of the feeding background of Iberian pigs using the fatty acid profile of subcutaneous muscle and hepatic fat. Meat Sci. 49, 155-163

SAS, 1999. Statistics. In: SAS User' Guide. Statistical Analysis System Institute Inc. Cary, NC

Sukhija P.S., Palmquist D.L., 1988. Rapid method for determination of total fatty acid content and composition of feedstuffs and feces. J. Agr. Food Chem. 36, 1202-1206

Tejeda J.F., Gandemer G., Antequera T., Viau M., García C., 2002. Lipid trait of muscles as related to genotype and fattening diet in Iberian pigs: total intramuscular lipids and triacylglycerols. Meat Sci. 60, 357-363 